\title{
Microscopical Society of Canada / Société de Microscopie du Canada 2014
}

\section{MSC-SMC Council Officers-Membres du Conseil}

doi:10.1017/S1431927614013191

\section{Executive Council / Conseil Exécutive}

$\begin{aligned} \text { President } & \text { Anja Geitmann } \\ \text { 1st Vice President } & \text { Michael Robertson } \\ \text { 2nd Vice President } & \text { TBA } \\ \text { Secretary } & \text { David O’Neil } \\ \text { Treasurer } & \text { Pierre Mathieu Charest } \\ \text { Past President } & \text { Randy Mikula }\end{aligned}$

\section{Councillors-at-Large}

\author{
Youssef Chebli \\ Martin Couillard \\ Jeff Fraser \\ Douglas Hall \\ Zygmunt Jakubek \\ Pen Li \\ Florence Perrin-Sarazin \\ Isabelle Rouiller \\ Stephen Wood
}

\section{Ex-Officio Council}

Executive Secretary

Bulletin Editor

Bulletin Advertising Manager

Webmaster

Zygmunt Jakubek

Pen Li

Florence Perrin-Sarazin

Isabelle Rouiller

Stephen Wood
Line Mongeon

Nadi Braidy

Dianne Moyles

Marin Lagace

\section{Section Chairs}

\section{MSC-SMC Sustaining Members / Membres}

Buehler Canada

Canemco-Marivac Limited

Edge Scientific

E.A. Fischione Instruments, Inc.

EDAX Inc.

Electron Microscopy Sciences

Fibics Inc.

Gatan Inc.

Hitachi High-Technologies Canada, Inc.

JEOL

Keyence Canada
Nikon Canada Instruments

OSRAM Sylvania Ltd/Ltée www.sylvania.com!

Oxford Instruments

Soquelec Ltd/Ltée

Spectra Research Corporation

SPI Supplies Canada

Systems for Research

Ted Pella, Inc.

Tescan

Carl Zeiss SMT 


\section{Microscopical Society of Canada / Société de Microscopie du Canada 2014}

\section{MSC-SMC Past Presidents / Anciens Presidents}

$\begin{array}{llll}\text { 1975-1977 } & \text { E.J. Chatfield } & 1993-1995 & \text { L. Arsenault } \\ 1977-1979 & \text { G.T. Simon } & 1995-1997 & \text { R. Sherbourne } \\ 1979-1981 & \text { G.H. Haggis } & 1997-1999 & \text { J. Corbett } \\ 1981-1983 & \text { F.P. Ottensmeyer } & 1999-2001 & \text { G. Harauz } \\ 1983-1984 & \text { D.A. Northwood } & 2001-2003 & \text { R. Gauvin } \\ 1984-1985 & \text { J.M. Sturgess } & 2003-2005 & \text { E. Humphrey } \\ 1985-1987 & \text { D.A. Graig } & 2005-2007 & \text { G. Botton } \\ 1987-1989 & \text { R.F. Egerton } & 2007-2009 & \text { C. Bennett } \\ 1989-1991 & \text { P.J. Lea } & 2009-2011 & \text { D. Beniac } \\ 1991-1993 & \text { G. L'Esperance } & 2011-2013 & \text { R. Mikula }\end{array}$

\section{SC-SMC 2013 Gérard T. Simon Award}

Haitian Xu, University of Victoria "Ultrafast Magnetic Imaging in Small Magnetic Elements".

Shelly Au, University of British Columbia "Baculovirus Nuclear Import: Open NPC Sesame”.

\section{The Canadian Foundation for the Development of Microscopy Travel Awards}

The Canadian Foundation for the Development of Microscopy (CFDM), an arm of the Microscopical Society of Canada, is a charitable organization whose aim is to promote the development of microscopy and associated techniques. Part of its mandate is to provide funds for educational opportunities for young scientists. In 2010 we are offering two awards to assist with the travel expenses of Canadian university students to participate in the Microscopy \& Microanalysis Conference. The Board of the CFDM will review submissions by students and evaluate them according to the following criteria: scientific merit, significance of their research, creativity, and a letter of reference. The deadline for submissions is May 1st and recipients are announced on the MSC website: http://www.msc-smc.org/. 


\section{Microscopical Society of Canada / Société de Microscopie du Canada 2014}

\section{CFDM Travel Award Winners (in conjunction with IUMAS)}

Samuel Bastien, Université de Sherbrooke.

Xiaohui Zhu, McMaster University.

The Francis Doane Award

In recognition for their outstanding service to the Microscopical Society of Canada

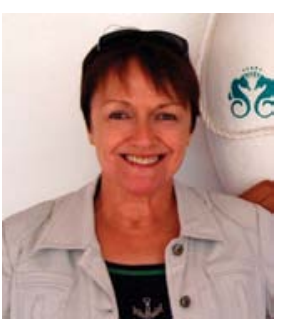

Odette Desbiens started her career in electron microscopy in 1968 at the Research Center of the Laval Hospital in Quebec City, working with pathologist Dr. Paul-Émile Roy. An internship in the laboratory of Dr. Rosita F. de Estable-Puig at the Faculty of Medicine of Laval University instilled in her the love for microscopy. In 1969, Odette joined the group of Dr. Georges Olah at the Faculty of Agricultural and Food Science at Laval University and had the opportunity to receive advanced training in microscopy in France, England, Germany, and in the US. In 1997 Odette moved to the new Life Sciences building of Laval University where she worked at the electron microscopy platform until her retirement in 2000.

Remarkably, Odette has been member of the Microscopical Society of Canada (MSC) ever since the very first annual meeting of the Society in 1974. She has assisted approximately 25 annual meetings of the Society and was involved in the organization of three of these. She completed three mandates as Councilor-at-large and then became council member ex officio as the first webmaster having set up the first web site of the MSC in 1999. She remained the webmaster and was active in the Society until 2010. Odette's service to the Society has been extraordinary. Her continuous dedication to the functioning of the MSC has been exemplary. By giving the Society an online presence, Odette single-handedly ensured the MSC's smooth transition to the 21st century. It is a great pleasure for the Society to recognize Odette's contribution by awarding her the Frances Doane Award.

\section{Past Francis Doane Award Winners}

Jim Corbett

Ray Egerton

Pierre-Mathieu Charest
2009

2010

2012
Rakesh Bhatnagar

Nancy Clark

Fran Leggett 